\title{
PLASMA CREATININE
}

\author{
BY \\ MARY RALSTON \\ From the Department of Chemical Pathology, Postgraduate Medical School, London
}

(RECEIVED FOR PUBLICATION JANUARY 25, 1955)

The non-specificity of reactions for creatinine is a well-recognized drawback in most methods for its determination. The Jaffé colour reaction which forms the basis of most procedures is given by numerous substances other than creatinine, over 30 being listed by Hunter (1928). They include, apart from substances related to creatinine, acetone, aceto-acetic acid, and pyruvic acid.

Various methods of estimating true creatinine as opposed to the total Jaffé-positive chromagen have been proposed. Miller and Dubos (1937), using suspensions of a creatininase-producing bacterium, carried out the Jaffé reaction on plasma filtrates before and after incubation with a suspension of the organism, and thus calculated the true creatinine by difference. According to this technique, the true plasma creatinine constituted $80-100 \%$ of the total chromagen. Methods employing adsorption on Lloyd's reagent have also been claimed to give true creatinine values. This substance is a hydrated aluminium silicate. In acid solution it adsorbs creatinine which can subsequently be eluted by alkali.

Recently Koštír and Šonka (1952) published a method for creatinine determination based on the observation that pyruvic acid is a Jaffé-positive substance which can be oxidized by ceric sulphate without destroying creatinine. Normal values found by this method were from 0.3 to $0.6 \mathrm{mg}$./ $100 \mathrm{ml}$. with a mean of $0.48 \mathrm{mg}$. $/ 100 \mathrm{ml}$. A series of determinations with ceric sulphate showed a reduction of $60 \%$ on a parallel series without ceric sulphate treatment. In our hands normal plasmas (11) treated with ceric sulphate by this method gave a range of 0.77 to $1.21 \mathrm{mg}$./100 ml., with a mean of $0.97 \mathrm{mg} . / 100 \mathrm{ml}$. This was a reduction of $16 \%$ on the values obtained on the same plasmas without ceric sulphate treatment. This reduction was significant but was not of the magnitude found by Koští̌ and Sonka.

We have also investigated the adsorption procedure with Lloyd's reagent (Fuller's earth) of Haugen and Blegen (1953) as modified by Owen, Iggo, Scandrett, and Stewart (1954), who found good agreement between the Lloyd's adsorption method and the specific enzymatic method. It was considered that another approach to checking its specificity would be to investigate the Lloyd's adsorbed material chromatographically. This method has given results which are lower than those obtained with the ceric sulphate method; and chromatograms of the eluates from the Lloyd's adsorption have shown only one Jaffé-positive spot, identical with that for creatinine. We conclude that the Lloyd's procedure is, in fact, specific for creatinine in plasma.

\section{Method}

Reagents.-The following are required:-

Sodium Tungstate. $-10 \%$.

Sulphuric Acid. $-\frac{2}{3} \mathrm{~N}$.

Lloyd's Reagent.-Fuller's earth B.D.H.: Haugen and Blegen (1953) point out that not all samples of Fuller's earth are suitable. Each batch should be tested for satisfactory adsorption.

Oxalic Acid.-Saturated solution.

Sodium Hydroxide. $-2.5 \mathrm{~N}-\mathrm{NaOH}$.

Picric Acid.-Saturated solution.

Alkaline Picric Solution.-Picric acid solution $(27.5 \mathrm{ml}$.) plus $2.5 \mathrm{~N}-\mathrm{NaOH}(5.5 \mathrm{ml}$.) made up to $100 \mathrm{ml}$. with water; prepared freshly for use.

Standard Creatinine Solution.-1 $\mathrm{mg} . / 100 \mathrm{ml}$. in water.

Procedure.-To $3 \mathrm{ml}$. of plasma is added $4.5 \mathrm{ml}$. of water, $1.5 \mathrm{ml}$. of sodium tungstate, and $3 \mathrm{ml}$. of $\frac{2}{3} \mathrm{~N}$ sulphuric acid. After thorough mixing and standing for $30 \mathrm{~min}$., the mixture is filtered through a No. 1 Whatman filter paper.

To $100 \mathrm{mg}$. ( $\pm 2 \mathrm{mg}$.) Lloyd's reagent in a centrifuge tube is added $5 \mathrm{ml}$. of filtrate (equivalent to $1.25 \mathrm{ml}$. plasma) and $0.5 \mathrm{ml}$. of saturated oxalic acid. The tube is stoppered and shaken intermittently for $10 \mathrm{~min}$. (As an alternative to weighing individual lots of the Lloyd's reagent, a suspension of $10 \mathrm{~g}$. in $100 \mathrm{ml}$. of water may be made and $1 \mathrm{ml}$. of this solution taken after thorough shaking.) The tube is then centrifuged at 3,000 r.p.m. for $20 \mathrm{~min}$. The supernatant is decanted and the tube allowed to drain.

To the packed deposit is added $7.5 \mathrm{ml}$. of freshly prepared alkaline picrate solution. The deposit is stirred, the tube stoppered and shaken intermittently for 
Solvent front

ferred as completely as possible to chromatogram paper (No. 1 Whatman).

With each sample of plasma a second sample of the same plasma, with added creatinine, was run. The creatinine $(10 \mu \mathrm{g}$. in $1 \mathrm{ml}$. of water) was added to the $5 \mathrm{ml}$. of filtrate, and adsorbed on Lloyd's reagent.

The chromatograms were run 16
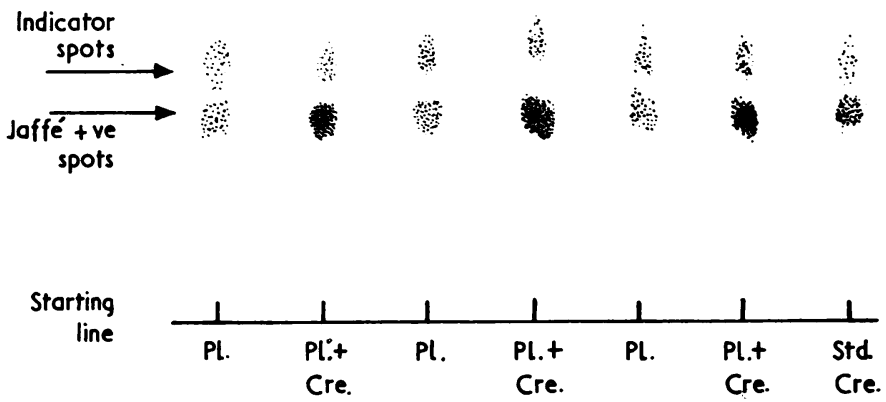

Fig. 1.-Chromatogram of eluates of Lloyd's adsorbed plasma (P1.), plasma plus icreatinine (Pl. + Cre.), and of creatinine standard solution (Std. Cre.). Run for 16 hours in butanol-acetic acid-water solvent, then sprayed with alkaline picrate solution.

$10 \mathrm{~min}$. It is centrifuged for $10 \mathrm{~min}$., and then placed in a water bath $\left(20^{\circ}-24^{\circ}\right.$ C.) and allowed to reach the bath temperature.

The solution is then read in a spectrophotometer at a wavelength of $520 \mathrm{~m} \mu$. Satisfactory results have also been obtained with the Ilford bright spectrum green light filter No. 624 in a photo-electric colorimeter.

A blank consisting of $5 \mathrm{ml}$. of water, and two $5 \mathrm{ml}$. standards containing $0.01 \mathrm{mg}$. and $0.025 \mathrm{mg}$. (equivalent to $0.8 \mathrm{mg}$. $(0.01 \times 100 / 1.25)$ and $2 \mathrm{mg}$. creatinine $/ 100 \mathrm{ml}$. plasma), are prepared in a similar manner, i.e., treated with Lloyd's reagent and alkaline picrate like the filtrate.

\section{Experiments}

Elution of Creatinine and Chromatography.Plasma was deproteinized, the filtrate allowed to stand in contact with Lloyd's reagent, the latter then centrifuged down and the tube drained. Sodium hydroxide, however, could not be used for elution as this interferes with obtaining satisfactory chromatograms. Hence other alkalis which could be removed before running the chromatogram were investigated. Ammonium hydroxide and potassium hydroxide proved unsuitable. A saturated solution of barium hydroxide, i.e., approximately $\mathrm{N} / 3$, was satisfactory. This was subsequently exactly neutralized by sulphuric acid using methyl orange as indicator. The precipitate of barium sulphate was spun down, the supernatant decanted and evaporated to dryness at reduced pressure at a temperature not exceeding $37^{\circ} \mathrm{C}$. It was then taken up in $0.1 \mathrm{ml}$. of distilled water and trans-

$\mathrm{Rf}$ value as the Jaffé-positive spot for plasma alone. The methyl orange indicator (contained in the test solutions) ran in advance of the Jaffé-positive spot.

It is considered that the results of these chromatograms indicate that Lloyd's reagent will adsorb
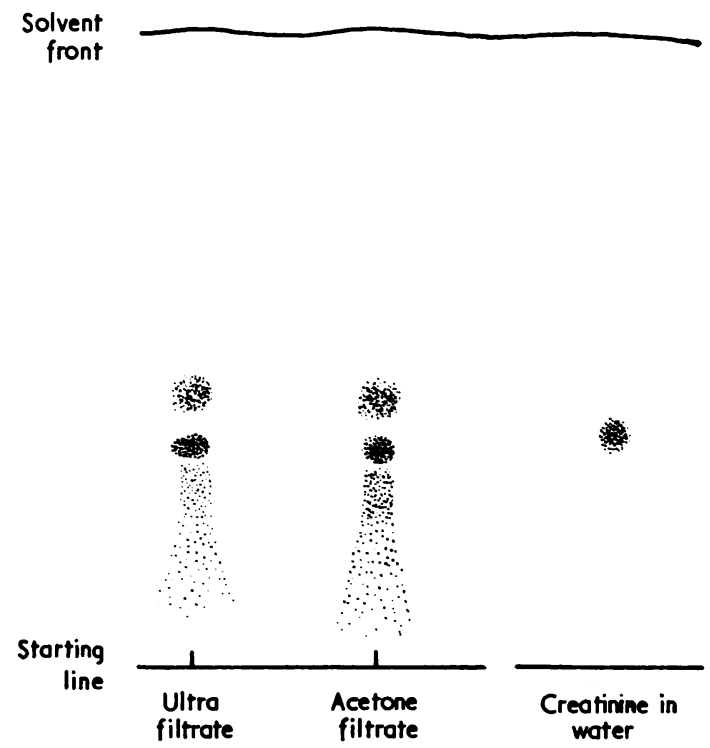

Fig. 2.- Chromatogram of plasma ultrafiltrate and of an acetone extract of plasma. Run for 16 hours in butanol-acetic acidwater solvent, then sprayed with alkaline picrate solution. Two Jaffé-positive spots were discerned in plasma together with streaking-" salt effect." 
creatinine alone of the Jaffé-positive substances present in plasma (Fig. 1).

Chromatograms were also run on ultrafiltrates of plasma and on plasma deproteinized with acetone. In these, salts are of course present and these interfere with the obtaining of clear-cut chromatograms. However, at least two spots were detectable (Fig. 2). Attempts at de-salting without destruction of the creatinine were unsuccessful.

TABLE I

PLASMA CREATININE VALUES BY DIFFERENT PROCEDURES (MG./100 ML.)

\begin{tabular}{c|c|c|c|c|c|c}
\hline $\begin{array}{c}\text { A } \\
\text { (Untal " } \\
\text { (Untreated } \\
\text { Plasma) }\end{array}$ & $\begin{array}{c}\text { B } \\
\text { After } \\
\text { Ceric } \\
\text { Sulphate }\end{array}$ & $\begin{array}{c}\text { Reduc- } \\
\text { tion } \\
\text { (\% B } \\
\text { on A) }\end{array}$ & $\begin{array}{c}\text { C } \\
\text { Treated } \\
\text { with } \\
\text { Lloyd's } \\
\text { Reagent }\end{array}$ & $\begin{array}{c}\text { Reduc- } \\
\text { tion } \\
\text { \% C } \\
\text { on A) }\end{array}$ & $\begin{array}{c}\text { D } \\
\text { Treated } \\
\text { with } \\
\text { Loyd's } \\
\text { and } \\
\text { Ceric } \\
\text { Sulphate }\end{array}$ & $\begin{array}{c}\text { Reduc- } \\
\text { tion } \\
\text { \% D D } \\
\text { on A) }\end{array}$ \\
\hline 1.29 & 1.13 & 12 & 0.86 & 33 & 0.82 & 36 \\
1.27 & 1.00 & 21 & 0.77 & 39 & 0.78 & 39 \\
1.34 & 1.00 & 25 & 0.91 & 32 & 0.92 & 31 \\
1.11 & 0.92 & 17 & 0.80 & 28 & 0.84 & 24 \\
1.08 & 0.94 & 13 & 0.80 & 26 & 0.76 & 30 \\
1.21 & 1.00 & 17 & 0.92 & 24 & 0.90 & 26 \\
1.18 & 0.98 & 17 & 0.80 & 32 & 0.84 & 29 \\
1.35 & 1.10 & 19 & 0.95 & 30 & 1.07 & 21 \\
1.04 & 0.90 & 13 & 0.70 & 33 & 0.74 & 29 \\
1.10 & 0.91 & 17 & 0.86 & 22 & 0.80 & 27 \\
\hline Average & 0.99 & 17 & 0.84 & 30 & 0.85 & 29 \\
1.20 & 0.99 & 17 & 0.84 & 30 & \\
\hline
\end{tabular}

As another method of checking the specificity of the Lloyd's adsorption technique, the material adsorbed on Lloyd's reagent after elution by alkali and subsequent neutralization of the alkali was then treated with ceric sulphate. For this purpose, tests of 10 normal plasmas were prepared in parallel in four different ways: (A) Untreated. with either ceric sulphate or Lloyd's reagent, i.e. total plasma creatinine; (B) treated with ceric sulphate; (C) treated with Lloyd's reagent; (D) treated with Lloyd's reagent followed by ceric sulphate.

No further reduction in the plasma creatinine value was obtained (Table I).

\section{Summary and Conclusions}

An investigation of certain methods of plasma creatinine determination is described. Treatment with ceric sulphate was found to give a slight reduction only of the "total" creatinine. The Lloyd's reagent adsorption procedure was investigated chromatographically and only one Jaffépositive substance, identical with that of creatinine similarly treated, was obtained.

It is concluded that the Jaffé-positive material measured by the Lloyd's adsorption method is creatinine and only creatinine. It appears that ceric sulphate treatment does not completely eliminate non-specific Jaffé-positive material.

I would like to thank Professor E. J. King and Dr. C. E. Dalgliesh for their help during these investigations, and Mr. D. Simmonds for the illustrations.

\section{REFERENCES}

Haugen, Scand. J. clin. Lab. Invest., $5,67$.

Hunter, A. (1928). Creatine and Creatinine (Monographs - on Biochemistry). Longmans, Green \& Co.

Koštír, J. V., and Šonka, J. (1952). Biochim. biophys. Acta, 8, 86.

Miller, B. F., and Dubos, R. (1937). J. biol. Chem., 121, 457.

Owen, J. A., Iggo, B., Scandrett, F. J., and Stewart, C. P. (1954). Biochem. J., 58, 426. 